\title{
The Values of Cultural Beliefs from Traditional Festivals Among the Khmer Mekong Delta - Study Typical Traditional Festivals
}

\author{
Nguyen Chi Hai ${ }^{1,2, *}$, Nguyen Ho Thanh ${ }^{1,2}$ \\ ${ }^{1}$ Department of National Defense Education, An Giang University, An Giang, Vietnam \\ ${ }^{2}$ Department of National Defense Education, Viet Nam National University Ho Chi Minh City, Ho Chi Minh City, Vietnam
}

Email address:

nchai@agu.edu.vn (N. C. Hai), nhothanh@agu.edu.vn (N. Ho Thanh)

${ }^{*}$ Corresponding author

To cite this article:

Nguyen Chi Hai, Nguyen Ho Thanh. The Values of Cultural Beliefs from Traditional Festivals Among the Khmer Mekong Delta - Study Typical Traditional Festivals. International Journal of Philosophy. Vol. 8, No. 4, 2020, pp. 82-87. doi: 10.11648/j.ijp.20200804.11

Received: October 26, 2020; Accepted: November 7, 2020; Published: November 16, 2020

\begin{abstract}
The cultural belief are a social phenomenon, it has inheritance, it always exists in the flow of the movement and development of history - society. Each ethnic group, with its historical conditions, has a traditional culture with its own unique, long-standing, and stable features, which is the national cultural identity. The cultural beliefs are a field with many special features and important values in the spiritual life of the Khmer people in the Mekong Delta. It is a combination of indigenous culture and religious culture. The article aims to highlight the cultural beliefs expressions of the Khmer Mekong Delta people through traditional festivals including Chol Chnam Thmay festival, Ok Om Bok festival, Pithi Sene Dolta festival. Traditional festivals of the Khmer in the Mekong Delta are influenced by Theravada Buddhism, so traditional festivals usually take place at the place associated with the temple, the form of the festival is also associated with the ritual of Theravada Buddhism. Their traditional festivals are deeply humane, expressed in such contents as filial piety, respect for grandparents, parents, gratitude to ancestors, living morally, living in harmony with nature. The article has pointed out the values of cultural beliefs through traditional festivals of the Mekong Delta people, it is expressed in their social life today. Therefore, research on cultural beliefs, traditional culture studies of the Khmer Mekong Delta is to study the social background, their creations, and their culture in social history. Thereby, we find out the characteristics and quintessence in the traditional value system, the nation's culture, in order to honor and promote these cultural values, and bring it to better service for the younger generation's life.
\end{abstract}

Keywords: The Cultural Beliefs, The Traditional Festivals, The Khmer People, The Mekong Delta

\section{Introduction}

The Khmer in the Mekong Delta, Vietnam currently has about 1.3 million people, they live mainly in the provinces of Tra Vinh, Soc Trang, Kien Giang, An Giang, Bac Lieu, Ca Mau, Hau Giang, Vinh Long, and Can Tho City [16]. The life of the Khmer is associated with wet rice cultivation and many handicrafts. The Khmer have a rich culture, they have built many temples with unique architecture. The Khmer had great festivals during the year, it was an opportunity to show the unique cultural activities of their people [13].

Most of the Khmer people live in villages, which surround the foothills or the Theravada Buddhist Temples [6]. The temple is the center of religious, cultural, and social activities, it is also a place to preserve and promote the cultural value of the nation, the Theravada Buddhist Temple has a close connection with the village where but the Khmer people are living. The Theravada Buddhist temple has a special role because it contains certain types of folk beliefs of the Khmer.

The cultural beliefs are a content that is concerned by the community in both theory and practice, it is the spiritual need of a part of the people, it is related to the fields of social life, impact on morality, economy, society [8]. The cultural beliefs are closely linked to the daily life of each person, each ethnic group. The Khmer people in the Mekong Delta always preserve their cultural, beliefs, and customs characteristics. In addition, the culture of the Khmer people exchanged and linked with other cultures in the region contributed to 
creating a rich and diversified culture, it enriched the culture of the Vietnamese nation.

Most of the Khmer in the Mekong Delta have Buddhist beliefs, the Theravada Buddhism [9]. Most young Khmer are cultivated in the spirit of Buddhism, learn Buddhist teachings, and study culture at the temple before entering the independent life of adults. They not only learn letters from the monks but also learn about morality, behavior, greeting grandparents, parents, teachers, and old people according to national customs. At the same time, they are also provided with basic knowledge of culture and arts by monks such as dances, folk singing, costumes, so that they can understand and preserve their own culture.

\section{Data and Research Methods}

In order to have a basis for researching and clarifying the problem posed. We have collected the information that has been verified from many sources. Secondary data includes collected information and data from official legal authorities. Primary data includes data collected from the survey and input from experts.

The article has been studied based on qualitative research methods. In addition, we have researched from other methods including historical and logical methods, synthesizing reference sources, on that basis we have generalized issues of practical nature.

\section{Overview of the Cultural Beliefs}

Culture has been a commonly used concept in social life, this term has not only many meanings in everyday language but also in different sciences. If we consider geographically, culture is divided into Eastern culture and Western culture. We can think that culture is what people create to form values, social norms in the working process, practical activities, that are specific to each nation [3]. These standard values influence and regulate the psychological, behavioral, ethical life and activities in all areas where human presence is present.

Belief is considered a heritage of national culture, it is a social phenomenon with historical nature. Belief is a category in relation to religion and it defines traditional values [4]. However, the distinction between religion and belief is only of a relative nature. In the social and linguistic life, both the terms religion and belief exist. When we are interested in belief, we are thinking about the sacredness of things, the phenomenon that is entrusted to human beings. Belief is a system of human beliefs about the sacred, natural, or social phenomena related to their lives in order to seek protection and help from metaphysical objects that their believer.

The cultural beliefs contain sacred and sensitive values for human spiritual life. Currently, cultural beliefs are interested in many cultural researchers, and they study in many different directions. The cultural beliefs are a system of values of human behavior towards nature or society related to their life. These methods and behaviors reflect the physical and spiritual conditions corresponding to the natural and social environmental conditions of a residential community.

Thus, the cultural beliefs are approached from tangible cultural values, intangible culture through worship facilities, worship rituals, folk anecdotes, rituals, festivals related to all forms of human beliefs including natural cult; human worship; real beliefs; Vietnamese Mothers' worship beliefs not only exist in abstract form but also exist in practice and practical behavior.

Table 1. List of Theravada Buddhism Khmer temples in the Mekong Delta

\begin{tabular}{llll}
\hline Zones & Number of temples & Number of Khmer people \\
\hline 1 & An Giang & 64 & 90.271 \\
2 & Bac Lieu & 22 & 70.667 \\
3 & Ca Mau & 7 & 29.845 \\
4 & Can Tho City & 12 & 21.414 \\
5 & Hau Giang & 15 & 21.169 \\
6 & Kien Giang & 74 & 210.899 \\
7 & Soc Trang & 92 & 397.014 \\
8 & Tra Vinh & 141 & 317.203 \\
9 & Vinh Long & 13 & 21.820 \\
\hline
\end{tabular}

\section{Research Results and Discussions}

\subsection{The Cultural Beliefs from the Traditional Festivals Among the Khmer People in the Mekong Delta}

The first, Chol Chnam Thmay (or Chaul Chnam Thmay) is a new year celebration of the Khmer in the world, Khmer community in the Mekong Delta also celebrates Chol Chnam Thmay. It is a valuable cultural long-standing of the Khmer people, Chol Chnam Thmay is an opportunity to connect family members together, it is also an opportunity for descendants to remember their ancestors or towards prices the traditional rule of the nation [11].

During the Chol Chnam Thmay festival, the Khmer people of the Mekong River Delta fully prepared offerings to worship the gods and the deceased. It is also an opportunity to honor grandparents, grandparents, parents, they wish for the best in life. According to the concept of the Khmer people, every year there is a god in heaven (called Teveda) sent by heaven to take care of human life in that year after one year he returns to heaven to let another god descend on earth.

The festival took place for 3 days. At New Year's Eve (the time of the beginning of the new year), Khmer families have prepared a tray of offerings, lit incense, lit a lamp to worship the old fairy to heaven (a god was in heaven), and welcome a new fairy down folk. Their family members at that time sat upright, lined up in front of the altar and prayed respectfully.

On the first day (called Chol Sangkran Chmay), the Khmer people bathed and dressed in beautiful clothes, brought incense and lanterns to the temple to hold a new calendar procession (called Maha sangkran). At the temple under the control of a monk, people lined up and walked around the main hall three times to celebrate the new year, and at the same time they wanted to see whether the new year was good 
or bad. After that, they went to the temple to worship Buddha and chant to celebrate the new year. At night, many people stayed to listen to the monks' sermons, while young men and women went to the temple courtyard to participate in games, dance, and singing activities.

On the second day, the Khmer people offered rice to the monks (called Ween Chong Hanh). According to custom, the devotees had to go to the temple to worship the Buddha, and they contributed to nourishing the monk by bringing rice and food to gather and invite the monks to eat. The monks chanted sutras, gave thanks to the people who made the food, and the monks chanted prayers to bless the devotees after the meal. After that, the Khmer people held a ceremony to build sandy mountains (called Phun Phnom Khsach). They brought in clean sand and piled them around the Theravada Buddhist temple outside the hallway in front of the temple grounds. A monk instructed them to build small mountains in nine directions, which symbolizes the universe, and a mountain in the middle corresponds to the heart of the world. The Khmer have poured sandy mountains in search of happiness, they prayed for good health.

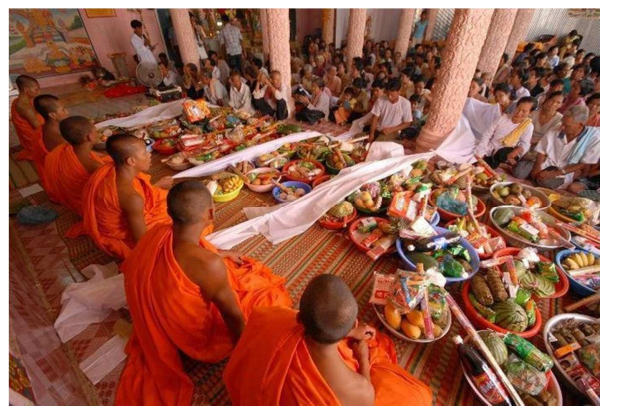

Figure 1. Khmer families brought food to the temple to present to the monks.

On the third day, the Khmer prepared fragrant water including rainwater and fresh flowers, they went to the temple to bathe the Buddha. After the Buddha bathing ceremony, the Khmer held a bathing ceremony for the elderly monks in the temple. After that, they went home to perform the Buddha bathing ceremony. All descendants of the Khmer family spread flower mats, invite grandparents and parents to sit down to ask forgiveness for the shortcomings and mistakes they have caused during the past year. Children and grandchildren have sincerely promised to correct their mistakes. Then they prayed together, they wished the new year the whole family would always meet many things of luck, joy, peace, and happiness. In the end, children and grandchildren bathed grandparents and parents to show their gratitude for the grace of birth and nurture.

The second, Ok Om Bok festival, also known as Moon Ceremony is a traditional festival of the Khmer people, held on October 14th and 15th of the lunar calendar every year. When the golden rice fields are harvested by Khmer farmers. To express their gratitude after a good harvest, the people of the Khmer River Delta offered their products to the moon god, the Buddha. Ok om bok festival is divided into two main parts, including the ceremony to worship the Moon God (called Pithi Sam Peak Preach Khe) and the Ngo boat racing festival.

Moon worshiping ceremony (Pithi Sam Peak Preach Khe). It is considered a unique cultural feature of the Khmer people of the Mekong Delta. After a season, the villagers gather together and set up on the table to offer foods such as flat rice, sugarcane, potatoes, beans, fruit with a pair of candles. The Ceremony of Moon Ceremony is considered by the Khmer people of the Cuu Long River Delta as an important ceremony for them to pray for the good weather, thank the good harvest, and wish for the next good harvest [19]. According to the concept of the Khmer people, the moon is the owner of the crops, and the moon is also the representative of the Buddha according to Buddhist relics.

Ngo boat racing (called Un Tuk) is the traditional festival in the Ok om bok festival of Khmer people in Cuu Long River Delta. Introducing the Ngo boat in this festival, Pham Thi Phuong Hanh came up with the concept, "The Ngo boat is a long curved boat. A racing boat has quite a special structure. The Ngo boat is made of fine wood, is well waterresistant, can withstand the extremely strong and flexible activity of more than 40 racers. In terms of structure, the Ngo boat has a body of about $25 \mathrm{~m}$ long, with the largest middle width up to $1.4 \mathrm{~m}$, smooth claws on both ends, only $0.4 \mathrm{~m}$. Inside the boat is placed horizontally on the double seat ladders from the beginning to the end of the boat,"[2]. The Ngo boat is a single wooden boat, originally used for travel (mainly military work). The form of boat racing was originally just a pair of small boats racing against each other. Later, the Khmer people in Cuu Long River Delta developed into one of the major festivals of the year.

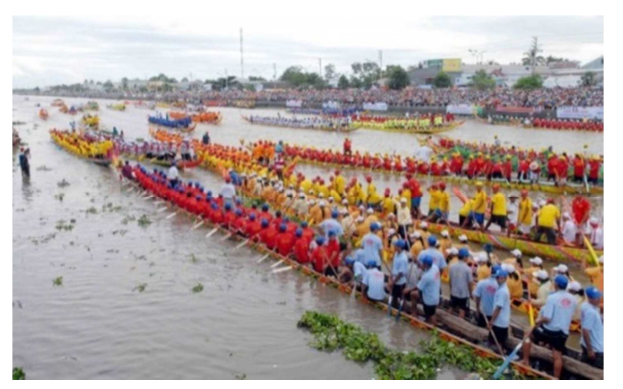

Figure 2. Ngo boat racing festival in Soc Trang, Cuu Long River Delta.

The Ngo boat represents a village or a Theravada Buddhist temple, each the Ngo boat is considered a precious and sacred property, so each Khmer temple has its own Ngo boat, and it is preserved at the temple. In the middle of the September lunar month (called Asock month), all Khmer Buddhists eagerly prepare for the Ngo boat racing festival. The rowers are healthy enough young men, and they are carefully selected in the village to participate in the festival. Ngo boat emulation festival has always been the enthusiastic attention of the Khmer people in Cuu Long River Delta. The ngo boat racing festival is usually held in Soc Trang provinces, but in recent years it also takes place in the provinces of Ca Mau, Bac Lieu, Kien Giang [14].

The third, the Pithi Sene Dolta festival is a traditional ritual with the unique beauty of the Khmer in the Mekong Delta. 
These special beauties are expressed in social and moral values. Pithi Sene DonTa festival of the Khmer has become an invisible cord connecting the Khmer community, creating great social values. It is the relationship between blood, clan, village, region, and religious community, ethnic community.

From the Pithi Sene Dolta Festival, the traditional cultural identity of the Khmer in the Mekong Delta is clearly formed, which are important factors including customs - festivals pagodas - monks are an inseparable cultural and spiritual symbol of the Khmer community, creating a cultural beauty during the Pithi Sene Dolta ceremony [18]. Therefore, in the cultural activities and rituals of the Khmer, the Mekong Delta tends to the source, which is the natural source that man was born.

Rites in the Pithi Sene Dolta ceremony, it has full humanistic educational value, implying the meanings of ethics, traditional morality, and behavioral lifestyle. It is shown through the rituals of giving thanks to land gods, water gods, ancestors, and commemorating the merits of ancestors. Therefore, they must respect their grandparents, grandparents, parents, politely, and keep the quality of virtue according to traditional morality. From these factors, we see that the Khmer people of the Mekong Delta are always interested in and cleverly integrate festive rituals with human education on traditional morals and morals. These are the ethical values that today need to be studied to preserve and promote.

On the occasion of the Pithi Sene Dolta festival, the Khmer in the Mekong Delta also regularly organizes the Bull Race Festival, a big traditional Khmer festival to show tribute and gratitude to their ancestors, and the merits of the dead. Every year during the season, many Khmer farmers from the villages flock to the Khmer pagoda to plow their fields. During that time, they invited each other to race the oxen for plowing, gradually becoming customary and being organized and awarded to the winners by the eldest monk in the temple. Since then, the Seven Nui Cow Race (the land of Tri Ton district, Tinh Bien province, An Giang province) has become the annual traditional bull racing festival of the Khmer in the Mekong Delta [17].

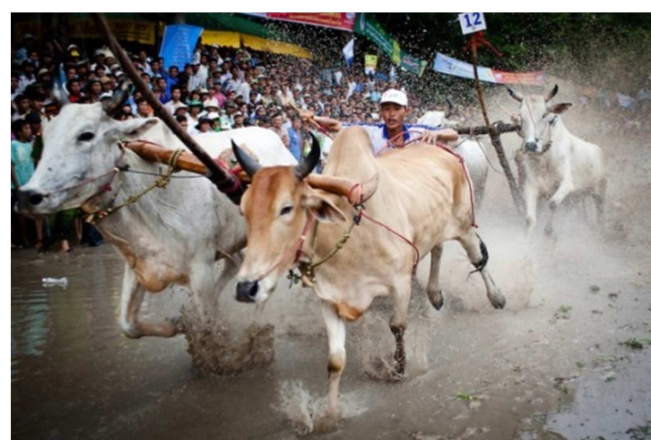

Figure 3. Cow racing festival in An Giang province, Mekong Delta.

\subsection{The Values of Cultural Beliefs from the Traditional Festivals Among the Khmer People in the Mekong Delta}

For a long time, the cultural beliefs had held a very important position in the spiritual life of the Khmer in the
Mekong Delta, it has been a typical culture of the Khmer people and it has the value to represent the Khmer people. The cultural beliefs of the Khmer in the Mekong River Delta have contributed to the diversification of Vietnamese culture.

The Khmer were present very early in the Mekong Delta, many temples of the Khmer people on this land have proved it. The Khmer have created for themselves an identity, a separate the cultural beliefs. When we thought of the cultural beliefs of the Khmer in the Mekong Delta, we saw it through the traditional festivals their. The valuation of these cultural beliefs was necessary for us to continue to study, preserve, and promote it. The traditional values of the Khmer in the Mekong Delta include faith, love for people, filial piety, community, hard work, and hard work.

Buddhist philosophy has become the main idea in the ideology of the Khmer in the Mekong Delta, they have put their faith in Theravada Buddhism [1]. The Khmer have a concept that, when they go to the temple and do good deeds, the more they can do, the better. Most of the Khmer had voluntarily considered themselves to be followers of Theravada Buddhism, they voluntarily associated their life with the temple from birth to death.

Theravada Buddhism has played a very important role in educating the Khmer's personality [10]. The humane philosophy and conception of the law of cause and effect of Buddhism have profoundly influenced members of the family, in the Khmer ethnic community. It has moved people towards goodness, has done it all well, and that philosophy has made the soul of the Khmer not clouded by material temptations.

The Theravada Buddhist Temple of the Khmer in the Mekong Delta was the center of their activity. The cultural beliefs activities have been carried out at the temple [7]. In addition to festivals, in the case of the Khmer when they are happy, sad, or in trouble they all go to the temple. In their families, or relatives have conflicts, they come to the temple for help and settlement. The pagoda is considered as a place to mediate disputes in the Khmer community. Everything that is complicated and troublesome is discussed at the temple. The pagoda also plays a role as a center for preserving and promoting the language, customs, and traditional morals of the Khmer people.

The Khmer pagoda has a particularly important role and position in their life, it is associated with all spiritual-cultural activities, beliefs, religions, and festivals of their people. The Khmer thought that Buddhism and the nation coexisted, so Theravada Buddhism and the Khmer people of the Mekong Delta were closely linked. Therefore, the values of cultural beliefs, ethnic traditions, and festivals of the Khmer Mekong River Delta are mixed together, it has a distinctive character. These values can be clearly seen in the following points.

Firstly, Theravada Buddhism dominates the entire spiritual life of Khmer. Most of the Khmer people believed and acted according to the Buddhist teachings, on that basis it helped people to do good, to bless, to accumulate merit, towards the roots, to show deep humanity, the tradition [15]. The good was handed down to generations to come. 
Secondly, the Theravada Buddhist temple for the Khmer was a sacred place and associated with their daily life, the pagoda was not only a place for religious activities but also a place for community activities, a place for learning, playing, and entertainment [5]. In addition, the pagoda was also a place to share all the joys and sorrows, difficulties in life, it was a place to preserve and promote ethical values and preserve the traditional cultural values of the whole nation. From these activities, the community of Khmer people has been clearly shown, creating conditions for people to bond, closer together, improve community solidarity.

Thirdly, all young people in Khmer families, when they are 12 years old or older, they have to go to the temple to practice. All men must know the Khmer language, thereby expressing their feelings and responsibilities to the ethnicity, and to pay homage to the Buddha, and to accumulate merit and accumulate knowledge for themselves [12].

Fourth, a unique feature in the Khmer's cultural and beliefs is that they do not distinguish between religious festivals or folk festivals. All of these festivals are held at the temple and the monk is the person with the most solemn position for them, decisive. With this content, the Khmer people in the Mekong Delta have made cultural heritage, the value of cultural beliefs preserved and handed down through generations.

\section{Conclusion}

The cultural belief are a social phenomenon with inheritance and sustainability, it always exists in the flow of the movement and development of history - society. Each ethnic group, with its conditions and history, has a traditional culture with its own characteristics, long-standing and stable, that is the national cultural identity.

The Khmer people in the Mekong Delta region have a rich, long-standing, and very unique culture. Therefore, we should study it, and we need many solutions to preserve and inherit the cultural values of the Khmer in the Mekong Delta region is very necessary today. If we do a good job in preserving and promoting the traditional values of the Khmer in the Mekong Delta, then not only will we be able to preserve the unique and proud culture of the Khmer, but also promoting that strength, contributing to building a beautiful Vietnam, and imbued with national identity.

\section{References}

[1] Bui Truong Xanh, "Human view of Buddhism in the spiritual life of the Khmer in Tri Ton district, An Giang province today". M. A Thesis, Ha Noi: Hanoi Pedagogical University, 2019.

[2] Pham Thi Phuong Hanh, "Khmer culture in the South - The beauty of the Vietnamese cultural identity". Ha Noi: National Political Publishing House, 2013.

[3] Truong Luu, "Khmer Culture in Mekong River Delta". Vietnam: Ha Noi People Culture Publishing House, 1993.
[4] Trinh Van Thanh, "The cultural beliefs in the spiritual life of Khmer An Giang people". M. A Thesis, Ha Noi: Hanoi Pedagogical University, 2016.

[5] Huynh Kim Dung, "Affection of Tourist toward Cultural Legacy of Khmer Theravada Buddhism at Tra Vinh Province", B. A Thesis, Ho Chi Minh City: Opening University, 2008.

[6] Mae Chee Huynh Kim Lan, "A study of Theravāda Buddhism in Vietnam", B. A Thesis, Bangkok: Mahachulalongkornrajavidyalaya University, 2010.

[7] Nguyen Si Lam, "Architecture of Khmer temple under Affection of Indian Buddhist Architecture and Thought". M. A Thesis, Ho Chi Minh City: Architecture University, 2004.

[8] Mai Phu Hop (2019). Solutions for the sustainable socioeconomic development on khmer community in the southern vietnam. AGU International Journal of Sciences - 2019, Vol. 7 (2), 68-78.

[9] Truong Ngoc Thuy (2012). Poverty Reduction Strategies in an Ethnic Minority Community: Multiple Definitions of Poverty among Khmer Villagers in the Mekong Delta, Vietnam. Asian Social Science. doi: 10.5539/ass.v8n6p196. URL: http://dx.doi.org/10.5539/ass.v8n6p196.

[10] Nguyen Van Thanh (2019). The value of the traditional ethics of the south khmer community through their relationship with nature. European Journal of Social Sciences Studies - 2019, Volume 4, Issue 4: 191-199. doi: 10.5281/zenodo.3405440.

[11] Vo Van Thang, Nguyen Hung Cuong, Nguyen Thi Ngoc Tho (2015). Traditional festivals in the south west khmer pagodas view from value perspectives. Journal of Science, An Giang University - 2015, Part A: Social Sciences, Humanities and Education, Vol. 1 (1), 1-8.

[12] Nguyen Quang Tuyen, Nguyen Thi Ngoc Mai (2016). Poverty Assessment and Analysis of Factors Affecting Income of the Poor Khmer Households in Loan My Village, Tam Binh District, Vinh Long Province. Global Journal of Human - Social Science: Economics, Volume 16 Issue 1 Version 1.0

[13] Truong Ngoc Thuy (2012). Impacts of poverty reduction strategies on an ethnic minority: a case study of a Khmer farming village in the Mekong Delta, Vietnam. M. A Thesis, Chiang Mai: Chiang Mai University.

[14] Nguyen Quang Tuyen (2010). Land Holding Changes and Kinh and Khmer Farmers' Livelihoods in Thoi Thuan B Hamlet, Thoi Lai Town, Co Do District, Can Tho City, Vietnam. Asian Social Science, Vol. 6, No. 1, 132-144.

[15] Ha Hong Nguyen, Nhan Van Nguyen (2019). Factor Affecting Poverty and Policy Implication of Poverty Reduction: A Case Study for the Khmer Ethnic People in Tra Vinh Province, Viet Nam. Journal of Asian Finance, Economics and Business, Vol 6, No1, 315-319. doi: 10.13106/jafeb.2019.vol6.no1.315.

[16] Van Da Huynh, Awais Piracha \& Hayley Saul (2019). Impact of Climate Change to Tourism Sector in the Vietnamese Mekong Delta. Review of European Studies, Vol. 11, No. 4, 44-59. doi: 10.5539/res.v11n4p44. URL: https://doi.org/10.5539/res.v11n4p44

[17] Nguyen Hoang Phuong (2019). Advantages and challenges for tourism in the Mekong Delta, Vietnam. International journal of scientific \& technology research, volume 8 , issue 09 , 13641368. 
[18] Vo Van Thang, Đinh Van To (2019). "Human philosophy in the Pithi Sene Dolta festival of the southern khmer". AGU International Journal of Sciences, Vol. 23 (2), 30-40.
[19] Huynh Thanh Quang (2010). "Promote Khmer cultural values to contribute to strengthening national solidarity". PhD Thesis, Ha Nội: Ho Chi Minh National Academy of Politics and Administration. 